DOI: https://doi.org/10.24144/2409-6857.2018.2(52).102-106

УДК [658.589+657.767]:005.21

Варава Л.М., Варава А.А.

\title{
ОПТИМІЗАЦІЯ УПРОВАДЖЕННЯ СТРАТЕГІЧНОГО ІННОВАЦІЙНО-ІНВЕСТИЦІЙНОГО ПРОЕКТУ НА ПРОМИСЛОВОМУ ПІДПРИЕМСТВІ
}

\begin{abstract}
У статті розглянуто умови оптимізаиії упровадження комплексного інноваційно-інвестиційного проекту, щзо розрахований на довгостроковий період і має у своєму складі ряд субпроектів. 3 даною метою для умов залізорудних гірничо-збагачувальних підприємств України визначено ряд інноваційних напрямів розвитку. Розроблено алгоритм дій щзодо формування стратегічного комплексного інновачійноінвестиційного проекту, оцінювання ефективності варіантів послідовності реалізації отриманого набору субпроектів $i$ визначення оптимального варіанту. Оптимізацію послідовності упровадження комплексного проекту виконано за допомогою економіко-математичних методів.
\end{abstract}

Ключові слова: стратегічний інноваційно-інвестиційний проект, субпроекти, критерії оцінки ефективності, оцінка ризику проекту.

Постановка проблеми. Сталий розвиток сучасних підприємств, їх успішне «виживання» у майбутньому пов'язаний 3 ефективною розробкою і реалізацією загальної стратегії. Як відомо, цілі, що обумовлюють загальну стратегію, досягаються шляхом управління комплексом інвестиційних програм i проектів. Для забезпечення довгострокових конкурентних переваг підприємству важливо планувати впровадження інновацій, особливо в пріоритетних напрямах діяльності діючої стратегіï.

Аналіз останніх досліджень і публікацій. В сучасних умовах розвитку підприємств, які можуть ускладнюватися кризовими явищами у галузі чи економіці в цілому, обмеженістю інвестиційних ресурсів саме інновації розглядаються багатьма науковцями як ключовий аспект підтримки i бізнесу та подолання негативних явищ. Важливою особистістю інноваційної діяльності підприємства є іï поєднання 3 питанням формування відповідних інвестиційних коштів. Тому у роботах набувають поширення інноваційно-інвестиційні аспекти забезпечення конкурентоспроможності підприємства та оптимізації його виробничого потенціалу. У цьому напрямі слід відмітити наукові праці С.В. Валдайцева [3], А.Е. Воронкової і Л.М. Кузь- менко [4], Крилова [7], С.Ф. Покропив-ного [10], та інших авторів. В них розглядаються основи управління

(C) Варава Лариса Миколаївна, д.е.н., проф., завідувач кафедри менеджменту і адміністрування, ДВНЗ «Криворізький національний університет», e-mail: larkumvar@gmail.com, тел. +380679322331

Варава Андрій Анатолійович, к.е.н., старший викладач кафедри менеджменту i адміністрування, ДВНЗ «Криворізький національний університет» e-mail: andvarava@i.ua, тел. +380981283736 інноваційно-інвестиційними проектами, методи оцінки їх ефективності, використання інновацій у антикризових заходах.

Останнім часом дослідження в основному зосереджуються на розвитку систем оцінювання і фінансування інноваційної діяльності, механізму стимулювання цієї сфери на підприємствах $[6,2$, 8]. В роботі А.Є. Никифорова [9] вивчаються ризики інноваційно-інвестиційної діяльності, визначено іiі функції та вплив на економічні фактори.

Слід відмітити дослідження Н.I. Чухрай та Л.С. Лісовської [11], де обгрунтовано технологію формування споживчої корисності інновацій за станами інноваційного процесу.

Узагальнюючи методологічні та прикладні підходи до розвитку та оцінювання інноваційноінвестиційної діяльності підприємств, слід надати особливе значення іiі стратегічному аспекту. Як правило результати та політика ІІД націлені на стратегічну перспективу, довгострокову конкурентоспроможність підприємства. Планування і реалізація ІІД відбувається в межах інноваційно-інвестиційної стратегії шляхом розробки стратегічних інноваційноінвестиційних проектів.

Практика показує, що упровадження таких проектів, які мають складну структуру, потребує оптимізації за певними критеріями. Їх вибір визначається окремими практичними ознаками $\mathrm{i}$ особливостями.

Формулювання цілей статті. Метою даного дослідження $\epsilon$ оптимізація за строками упровадження комплексного інноваційноінвестиційного проекту (КІІП) шляхом формування раціональної послідовності реалізації субпроектів, що входять до його складу, та вибору ефективного варіанту стратегічного розвитку гірничо-збагачувального 
підприємства.

Опис основного матеріалу дослідження. На великих підприємствах гірничо-металургійної промисловості України впроваджуються стратегічні інноваційно-інвестиційні проекти, які мають комплексний характер, i включають значну кількість «локальних» субпроектів. Серед них: розширення й реконструкція діючих цехів, удосконалення основних технологічних процесів, транспортної схеми, введення нових технологічних операцій та ін.

Вирішення проблеми реконструкції здійснюється в умовах значного дефіциту інвестиційних коштів у сировинному комплексі. Очевидно, що в цьому випадку при визначенні послідовності упровадження заходів, що забезпечують ефективний розвиток підприємства, необхідно вибрати оптимальне інвестиційне рішення, яке полягає у визначенні раціонального варіанта набору реалізуємих інвестиційних проектів на стратегічну перспективу.

До завдання оптимізації комплексного інноваційно-інвестиційного проекту (в подальшому КІІП), що розрахований на довгостроковий період упровадження, належить досягнення найкращого варіанту за прибутковістю інвестиційних коштів та строком окупності. Для цього передбачено визначити оптимальний варіант строків упровадження складових субпроектів КІІП у запланованому для ï реалізації стратегічному періоді. Таким чином, необхідно забезпечити формування раціональної послідовності реалізації інноваційних субпроектів, що входять до складу КІІП. При цьому, слід зробити вибір ефективного варіанту розвитку підприємства 3 урахуванням інноваційно-інвестиційних рішень за стратегічними напрямами діяльності.

Для вирішення поставленого завдання передбачено виконати такі дії: 1) на основі загальної стратегії розвитку підприємства сформувати стратегічний КІІП, що включає ряд субпроектів, реалізація яких забезпечує досягнення поставлених стратегічних цілей; 2) розробити методику формування варіантів стратегічного КІІП 3 урахуванням вибору субпроектів «найвищого пріоритету»;3) оцінити ефективність сформованих варіантів стратегічного КІІП, використовуючи ряд відповідних критеріїв;4) визначити оптимальний варіант послідовності упровадження отриманого набору субпроектів, які входять у стратегічний КІІП.

В сучасних умовах визначено ряд інноваційних напрямів розвитку залізорудних гірничодобувних підприємств України.
Відокремити їх можна за певними стратегічними напрямами.

До них належать: 1) підтримка та розвиток виробничих потужностей; 2) впровадження нових технологій;3) підвищення якості залізорудної продукції:

Якщо розглядати окремі складові зазначених інноваційних напрямів в межах одного підприємства як субпроекти, що мають бути реалізовані впродовж стратегічного періоду, то на ïх основі може бути сформований КІІ. Оптимальна послідовність набору субпроектів повинна бути сформована також 3 урахуванням обов'язкових строків упровадження «пріоритетних» проектів, виконання яких має першочергове значення для подальшої реалізації стратегічного КІІП й майбутнього розвитку підприємства.

Набір субпроектів за стратегічними напрямами, що були розглянуті вище, формується 3 тих, які відібрані підприємством для впровадження i визнані експертами як інноваційні, що мають позитивні прогнозні результати на довгострокову перспективу.

Завдання оптимізації упровадження складових КІІП стратегічного розвитку основного виробництва на прикладі гірничозбагачувального комбінату (ГЗК) ставиться в аспекті формування набору субпроектів за визначеними напрямами так:

Нехай є деяка кількість "локальних" проектів $L_{s}, s=\overline{1, f}$. Задано ряд критеріальних показників, які враховуються при формуванні проекту: $K_{l}$, $K_{2}, \ldots K_{n}$. У даному завданні як критерії беруться: загальний обсяг інвестицій за проектом, річний обсяг інвестицій, чиста поточна вартість проекту, рентабельність інвестицій, період окупності, внутрішня норма окупності. Серед заданих показників вибирається головний критерій $-K_{\text {гол }}$

Необхідно сформувати послідовність часу початку реалізації кожного субпроекту:

$$
\left\{T_{1}^{(k)}, T_{2}^{(l)}, \ldots T_{p}^{(f)}\right\}
$$

де $T_{i}^{(s)}$ - момент початку реалізації $s$-го субпроекту, що виконується в і-у чергу; $k, l, f-$ номера субпроектів; $1,2 \ldots p$ - номер черговості, за якою вони реалізуються, $p \leq z$ i $K_{t}=f\left(T_{I}{ }^{(k)}\right.$, $\left.T_{2}^{(l)}, \ldots T_{p}^{(f)}\right), t=\overline{1, n} \ldots$

При цьому головний критерій повинен набувати екстремального значення $\left(K_{\text {гол }} \rightarrow\right.$ extr) 3 урахуванням виконання обмежень за іншими показниками:

Загальне описання алгоритму

1. Уведення вихідної інформації. Задаються попит (планові показники продажів концентрату - $\left(Q_{n p}\right)$ і ціни на концентрат $\bigsqcup_{\kappa}$; інформація за кожним субпроектом-обсяги інвестицій $I_{r j}$ за 
роками реалізації пріоритетних та інших проектів; обмеження за загальним $I_{3}$ і річними обсягами інвестицій $I_{t}$.

2. Уведення інформації про зміни вихідних показників: обсягів концентрату $Q_{k j}$, ціни концентрату $L_{k j}$, що отримується унаслідок реалізації $j$-х інноваційних субпроектів за роками стратегічного розвитку.

3. Уведення даних про зміни складових витрат залежно від року реалізації $j$-х «пріоритетних» субпроектів.

4. Те ж, залежно від року реалізації $j$-х субпроектів «нижчого рангу».

5. Вибір серії проектів «нижчого рангу».

6. Перебирання всіх варіантів для серії за умови, що для кожного $t$-го року обсяг інвестицій $I_{t}$ не перевищує заданої величини, тобто $I_{t} \square I_{t}^{3}$. Отже,

$$
I_{t}=\sum_{j=1}^{J} I_{\mathrm{jt}} \lambda_{\mathrm{jt}} \leq I_{t}^{3},
$$

де $I_{j t}-$ обсяг інвестицій за $j$-м проектом в $t$-му році; $\lambda_{j t}-$ булева змінна, що набуває значення 1 або 0 ,

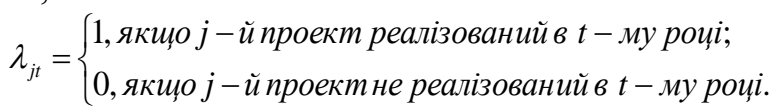

7. Обчислення показників: виторгу для кожного $t$-го року реалізації КІІП, змінних $\mathrm{i}$ умовно-постійних витрат, прибутку, грошового потоку від операційної діяльності.

8. Розрахунок інвестиційних коштів.

8.1 Обсяг інвестицій, що фінансуються за рахунок власного капіталу підприємства за роками реалізації проекту

$$
I_{s t}=\sum I_{s j t} \cdot \lambda_{j t} \cdot \partial_{t},
$$

де $I_{j t}$ - обсяг інвестицій за $j$-м проектом, що фінансується за рахунок власного капіталу; $\partial_{t}$ булева змінна,

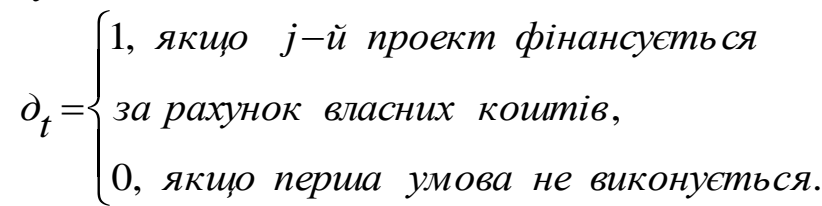

8.2. Уведення суми довгострокового кредиту за роками реалізації $K_{t}$.

8.3. Розрахунок обсягу інвестицій, залученого з боку інвесторів

$$
I_{3 \text { лा }}=I_{t}-I_{\mathrm{Bt}}-K_{t} .
$$

8.4. Розрахунок грошового потоку від фінансової діяльності $F^{\phi}$ :

$$
F_{t}^{\phi}=I_{\mathrm{Bt}}+I_{3 \mathrm{st}}+K_{t}-\mathrm{B}_{\mathrm{\kappa pt}}
$$

9. Розрахунок показників інвестиційної діяльності:

ефекту від інвестиційної діяльності

$$
E_{t}=\sum_{j=1}^{F} e_{\mathrm{Bjt}} \cdot \lambda_{\mathrm{jt}},
$$

результуючого грошового потоку $C F_{t}$ у t-му році

$$
\mathrm{CF}_{t}=F_{t}^{0}+F_{t}^{\phi}+E_{t} .
$$

10. Оцінка ефективності розглянутого варіанта КІІІ.

3 використанням розробленої методики авторами було виконано ряд серій експериментів 3 метою вибору раціонального варіанта стратегічного розвитку основного виробництва ГЗК з урахуванням інноваційно-інвестиційних рішень 3 удосконалення технологічних процесів, підвищення якості й збільшення обсягів виробництва кінцевої продукції.

Як головний критерій оцінки ефективності проекту використовується чиста поточна вартість $N P V[1 ; 5]$. Як додаткові показники ефективності, що доповнюють вибір варіанта КІІП, застосовувалися: рентабельність інвестицій (PI) $[1 ; 5]$; період окупності інвестицій $(P P)$ розраховується за $[5$, с.106-113]; внутрішня норма окупності проекту (IRR) $[1 ; 5]$.

11. Оцінка ризику розглянутого варіанту КІІП.

Застосовується метод аналітичного моделювання. Як вихідні дані встановлюються параметри специфічних ризиків за окремими видами субпроектів, що мають певну ймовірність виявитися у відповідні періоди стратегічного розвитку. При виборі варіанта стратегічного КІІП варто враховувати кількісну оцінку специфічних ризиків окремих інноваційних субпроектів, що формує величину загального ризику проекту $\mathrm{R}_{3}$.

$$
\mathrm{y} \text { підсумку, визначається }
$$
середньоквадратичне відхилення грошового потоку в $\mathrm{t}$-му періоді i відхилення за результуючими показниками стратегічного КІІП.

3 кожної серії вибирається варіант із максимальним значенням NPV. У випадку створення нової серії - повернення до п.5.

12. Вибір оптимального варіанта реалізації стратегічного проекту на основі кращих варіантів серій з урахуванням комплексного ризику.

Результати розрахунків з вибору оптимального варіанта реалізації КІІП містяться у табл. 1 та на рис. 1.

Висновки та перспективи подальших досліджень. В цілому, слід зазначити, що чутливість проекту, за розрахунком, невисока. Середній рівень беззбиткового виробництва за 
Результуючі показники за розглянутими варіантами

\begin{tabular}{|c|c|c|c|c|c|}
\hline \multirow{2}{*}{ № } & $\begin{array}{c}\text { Чиста поточна } \\
\text { вартість проекту } \\
\text { (NPV), тис.грн. }\end{array}$ & $\begin{array}{c}\text { Рентабельніст } \\
\text { в інвестицій } \\
\text { (РI), } \\
\text { ч.од. }\end{array}$ & $\begin{array}{c}\text { Період } \\
\text { окупності } \\
\text { інвестицій, } \\
\text { (РP), роки }\end{array}$ & $\begin{array}{c}\text { NPVр, } \\
\text { тис.грн. }\end{array}$ & $\begin{array}{c}\text { Внутрішня } \\
\text { норма } \\
\text { окупності } \\
\text { (IRR), } \%\end{array}$ \\
\hline Серія1Варіант1 & 158075,578 & 1,42483 & 4,42192 & 119539,6 & 44,54 \\
\hline Серія1Варіант2 & 157444,060 & 1,64058 & 4,54003 & 118948,2 & 44,15 \\
\hline Серія1Варіант3 & 152902,066 & 1,61977 & 4,54723 & 114411,3 & 43,23 \\
\hline Серія1Варіант4 & 152748,866 & 1,61919 & 4,54723 & 114283,9 & 43,19 \\
\hline Серія1Варіант5 & 158278,175 & 1,64484 & 4,54054 & 119685,2 & 44,81 \\
\hline Серія2Варіант1 & 151575,522 & 1,61127 & 4,55065 & 112834,9 & 43,03 \\
\hline Серія2Варіант2 & 150771,032 & 1,60830 & 4,55151 & 111996,8 & 42,84 \\
\hline Серія2Варіант3 & 155583,988 & 1,63232 & 4,54337 & 116794,1 & 43,96 \\
\hline Серія2Варіант4 & 155213,185 & 1,63271 & 4,54427 & 116424,9 & 44,17 \\
\hline Серія2Варіант5 & 156462,480 & 1,63374 & 4,54309 & 117664,9 & 44,08 \\
\hline Серія3Варіант1 & 152659,808 & 1,61961 & 4,54756 & 114065,6 & 43,31 \\
\hline Серія3Варіант2 & 152261,746 & 1,61903 & 4,54744 & 113734,9 & 43,21 \\
\hline Серія3Варіант3 & 156289,548 & 1,64169 & 4,54019 & 117804,5 & 44,33 \\
\hline Серія3Варіант4 & 156423,597 & 1,64105 & 4,54019 & 117931,8 & 44,28 \\
\hline Серія3Варіант5 & 157116,016 & 1,64229 & 4,54047 & 118498,4 & 44,52 \\
\hline Серія4Варіант1 & 159995,801 & 1,67642 & 4,52726 & 121408,1 & 45,65 \\
\hline Серія5Варіант1 & 159671,227 & 1,67352 & 4,52811 & 120849,0 & 45,43 \\
\hline Серія6Варіант1 & 159927,074 & 1,67244 & 4,52839 & 121297,5 & 45,48 \\
\hline Серія7Варіант1 & 159977,034 & 1,67627 & 4,52740 & 121366,8 & 45,66 \\
\hline
\end{tabular}

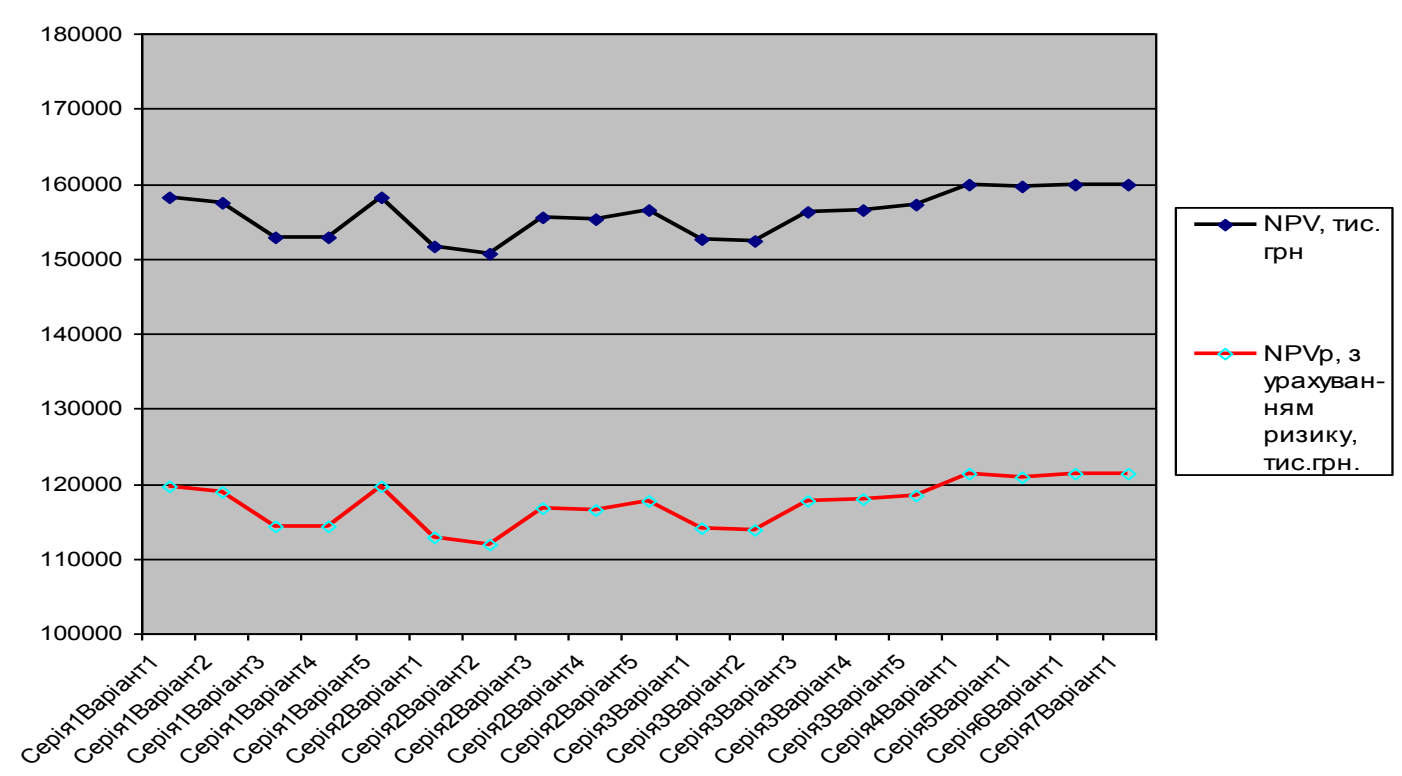

\section{Рис.1. Чиста поточна вартість за варіантами проекту без урахування й з урахуванням комплексного ризику*}

*Джерело: авторська розробка

варіантами не перевищує $66-70 \%$ від прогнозованих показників. 3 метою досягнення найкращих результатів реалізації стратегічного КІІП було сформульовано й вирішено завдання вибору оптимального варіанту набору субпроектів, які забезпечують упровадження заходів щодо окремих напрямів діяльності. Вибір раціональної послідовності реалізації стратегічного проектного набору дозволяе підвищити в порівнянні з первісним варіантом рентабельність інвестицій у 1,2 рази, а строк повернення інвестицій скоротити у 1,35 рази.

Подальші дослідження авторів спрямовані на удосконалення інноваційно-інвестиційних стратегій у напрямі формування системи показників, що визначають конкурентоспроможність підприємств у стратегічній перспективі та дозволяють оцінювати ефективність упровадження зазначених вище проектів. 


\section{ПЕРЕЛІК ВИКОРИСТАНИХ ДЖЕРЕЛ}

1. Бирман Г. Экономический анализ инвестиционных проектов/Г. Бирман, С. Шмидт. - М.: Банки и биржи, ЮНИТИ, 1997. - 631 с.

2. Бояринова К.О. Актуалізація та передумови оцінювання інноваційної адаптивності підприємства/ Актуальні проблеми економіки/К.О. Бояринова, Т.В. Войтун//Актуальні проблеми економіки. - 2015. - №1. C. $138-144$

3. Валдайцев С.В. Антикризисное управление на основе инноваций/Валдайцев С.В. - СПб.: Изд-во С-Пб унив-та, 2001. - 232 с.

4. Воронкова А.Э. Инвестиционное обеспечение инновационных проектов/А.Э. Воронкова, Л.М. Кузьменко//Вісник Академії економічних наук України. - 2003. - №1. - С.49 - 53.

5. Гойко А.Ф. Методи оцінки ефективності інвестицій та пріоритетні напрями їх реалізації/Гойко А.Ф.: Монографія. - К.:ВIPA - P, 1999. - 320 с.

6. Колодізєв О.М. Формування багаторівневої системи показників фінансування інноваційної діяльності/ актуальні проблеми економіки/Колодізєв О.М.//Актуальні проблеми економіки. - 2013. - №8. - С.32 - 44

7. Крылов Э.И. Методологические вопросы управления процессами реализации инновационноинвестиционных проектов/Крылов Э.И., Власова В.М., Пешкова Г.Ю.: Монография. - СПб.: ГУАП - У, 2011. $252 \mathrm{c}$.

8. Нижник В.М. Механізм стимулювання інноваційної спроможності промислових підприємств/В.М. Нижник, В.Ф. Лещук//Актуальні проблеми економіки. - 2015. - №1 . - С.173 - 177

9. Никифоров А.Є. Ризики інноваційно-інвестиційної діяльності та їх роль у розвитку економіки/Никифоров А.Є.//Актуальні проблеми економіки. - 2015. - №8. - С.45 - 52

10. Покропивний С.Ф. Ефективність інноваційно-інвестиційної діяльності/С.Ф. Покропивний, А.П. Новак К.:КНЕУ, 1997. - 184 c.

11. Чухрай Н.І. Формування споживчої корисності інновації/Н.І. Чухрай, Л.С. Лісовська//Актуальні проблеми економіки. - 2013. - №11. - С.27 - 34

\section{REFERENCES}

1. Birman, H. \& Shmidt, S.(1997). Jekonomycheskij analiz investicionnyh proektov [Economic analysis of investment projects]. Moskva: Banki i birzhi, JuNYTY[ in Russian].

2. Boyarynova, K.O. (2015). Aktualizatsiia ta peredumovy otsinyiuvannia innovatsiynoi adaptyvnosti pidpryiemstva [Actualization and preconditions of enterprise's innovative adaptability estimation]. Aktualni problemy ekonomiky Actual problems of the economy, 1, 138-144 [in Ukrainian].

3. Valdajcev, S.V. (2001). Antikrizisnoe upravlenie na osnove innovacij [Anti-crisis management based on innovation]. Sankt-Peterburg: isdatel'stvo S-Pb Universiteta [in Russian].

4. Voronkova, A.Je. \& Kuz'menko, L.M. (2003). Investicionnoe obespechenie innovacionnyh proektov [Investment support of innovation projects]. Visnyk Akademii ekonomichnykh nauk Ukarainy - Bulletin of the Academy of Economic Sciences of Ukraine, 1, 49 - 53 [in Russian]

5. Goiko, A.F. (1999) Metody otsinky efektyvnosti investitsii ta priorytetni napriamy yikh realizatsii [Methods of assessing the efficiency of investments and priority directions of their implementation]. Kyiv: VIRA - R [in Ukrainian]

6. Kolodiziev, O.M. (2013) Formuvannia bahatorivnevoi systemy pokaznykiv finansuvannia innovatsiinoi diialnosti [Formation of multilevel system of indices on innovative activity financing]. Aktualni problemy ekonomiky - Actual problems of the economy, 8, $32-44$ [in Ukrainian]

7. Krylov, Je.I., Vlasova, V.M. \& Peshkova, G. Yu. (2011). Metodolohicheskie voprosy upravleniya processami realizacii innovacionno-investicionnyh proektov [Methodological issues of managing the implementation of innovative investment projects]. Sankt-Peterburg: GUAP - U [in Russian].

8. Nyzhnyk, V.M. (2015) Mekhanizm stymuliuvannia innovatsiinoi spromozhnosti promyslovykh pidpryiemstv [Mechanism of enhancing the innovative capacity of industrial enterprises]. Aktualni problemy ekonomiky - Actual Problems of Economy, 1, 173 - 177 [in Ukrainian].

9. Nykyforov, A.Ye. (2015) Ryzyky innovatsiino-investytsiinoi diialnosti ta yikh rol u rozvytku ekonomiky [Risks in innovative investment activity and their role in economic development]. Aktualni problemy ekonomiky - Actual problems of the economy, 8, $45-52$ [in Ukrainian].

10. Pokropyvnyi, S.F. \& Novak, A.P. (1997) Efektyvnist innovatsiino-investytsiinoi diialnosti [Efficiency of innovation and investment activity]. Kyiv: KNEU [in Ukrainian].

11. Chukhrai, N.I. \& Lisovska, L.S. (2013). Formuvannia spozhyvchoi korysnosti innovatsii [Formation of innovation's consumer utility]. Aktualni problemy ekonomiky - Actual problems of the economy, 11, 27 - 34 [in Ukrainian]. 